\title{
Reversing the Brain Drain of Human Capital through China Pakistan Economic Corridor
}

\author{
Dr. Fahad Khan Afridi \\ Assistant Professor, Department of Management Sciences \\ Qurtuba University of Science and Technology \\ fafridi449@gmail.com \\ Dr. Muhammad Asif \\ Assistant Professor, Management Sciences Department \\ City University of Science and I.T. Peshawar \\ asifbaloch@cusit.edu.pk \\ Dr. Rashda Qazi \\ Ghazi University, Dera Ghazi Khan \\ Rashida_qazi@yahoo.com \\ Dr. Waleed Afridi \\ wafridy@gmail.com
}

\begin{abstract}
The research aims to assess the effect of CPEC on reversing the brain drain of Pakistan's human capital. The research study is based on secondary data by using research articles, economic surveys, Bureau of Immigration and Overseas Employment etc. CPEC being a multibillion-dollar "Game Changer" can enhance the socio-commerce dimensions by reversing the brain drain of human capital of the country. It can only be possible by devising a viable strategic plan by the government for "Diaspora engagement policies". The local and overseas Pakistanis should be involved in the projects only through their mobilization and engagement just like China and India did. Although, the present research article gives an insight to socio-economic impact of CPEC on Pakistan.
\end{abstract}

Key Words: CPEC, Brain Drain, Human Capital, Pakistan

\section{Introduction}

Brain Dain is a global phenomenon, which has affected many countries of the world. Developing countries are the most affected countries from the phenomenon, as it deprived them of its human capital, resultantly, lowering down the socio economic development of those countries (Dodani \& Porte, 2005). Pakistan, being a developing country is of no exception, hence, facing the loss of human capital. According to Bureau of immigration and Overseas Employment (2015) statistics, 8771567 skilled and educated labor including doctors, engineers and other professionals have been migrated 
to different countries of the world from 1971-2015. Owing to the reason, overseas Pakistanis become the $5^{\text {th }}$ largest diaspora of the world with total 600,000 populations (International Migration Report, 2017). Such large scale out flow of human capital is a source of decelerating socio economic progress and resultantly "Brain Drain" of talented workforce occurs (Afridi \& Baloch, 2015; Afridi, Baloch \& Baloch, 2016). Although, the financial gains in terms of foreign remittances are worth mentioning, however, their contribution to the GDP is merely $7.2 \%$ (Personal remittances, received \% of GDP, n.d). The effect of brain drain in terms of human capital can be mitigated if it is reversed through bringing the drain out human capital back to the country through mega developmental projects such as China Pakistan Economic Corridor (CPEC) (Afridi \& Baloch, 2015; Afridi \& Urooj, 2020). Such mega projects not only have the potential to prevent the human capital flight of the skilled workforce rather a source of "brain gain" and "brain circulation". The research paper aims to assess the significance of CPEC " $a$ game changer" on reversing brain drain of human capital of Pakistan. The article comprises of following four parts.

First part consists of a brief overview of CPEC and its impact on brain drain. Second part describes diaspora engagement and CPEC, third part has recommendations on the basis of analysis and part four comprise of conclusion.

\section{CPEC and Brain Drain of Pakistan}

China Pakistan Economic Corridor (CPEC) is a joint collaboration of the Government of Pakistan and People Republic of China to boost up economic ties between the countries. The total cost of the project is almost 46 billion dollars comprising of 38 projects of energy, infrastructure and railroads (Butt, $16^{\text {th }}$ July 2016). As far its financial impact is concerned, the total investment of the project is equivalent to the sum of all foreign direct investments since 1970 (Rakisits, 2015) and upon completion, it will raise the 2015 GDP of Pakistan to $17 \%$ (Khan, $3^{\text {rd }}$ December, 2015). According to the Ministry of Planning Commission (2015), it would create approximately 2,000,000 jobs in different fields such as mechanical, electrical, civil and telecommunication engineering. Besides, it would also create jobs in agriculture sector, as the $2,442 \mathrm{~km}$ economic corridor would be stretched from China's northwestern region of Xingjiang to the South-western port of Gawadar (Zhen, $11^{\text {th }}$ November, 2015). Such heavy investment of billion dollars in infrastructure and communication requires a lot of human capital for the economic development of the country. More specifically, 2,000,000 more highly skilled and educated human resource is required for the successful completion of the project (Ministry of Planning, Development and Reforms, 2016-17). Interestingly the labour force has increased in number more than general population growth rate with an estimated ratio of $2.9 \%$ ( Ahmad,Cho \& Fasih, 2019) A close analysis of our existing human capital entails that the national human capital stock is empty of it. The flight of human capital at an accelerating speed to other countries and regions of the world is creating labor shortage. According to Imran, Azeem, Haider and Bhatti (2011), each year, approximately 4000 physicians are 
leaving the country. Similarly, the Bureau of Immigration and Overseas Employment (2015) report states that 8771567 human capital of different occupations ranging from labor to physicians have migrated abroad. The net migration of Pakistan is -1.54 according to 2015 est. (CIA Facts File, 2015), which implies emigration exceeds immigration. The massive rate of brain drain is due to the lack of feasible socio, economic and political conditions (Sajjad, 2011). Lack of mega projects like CPEC is also another reason for the human capital flight (Afridi \& Baloch, 2016). To conclude, the "billion dollar game changer" can lead to reversing and further perverting the brain drain of human capital. According to Pakistan Engineering Council the total number of registered engineers is 170,992, with Electrical engineers 41,400, Civil engineers 35,419, mechanical engineers 27,076 and others 67,097(PEC, 2014). These engineers can immediately fill the vacancies created by CPEC. Resultantly, the brain drain of engineers will be prevented.

\section{Diaspora Engagement and CPEC}

Diaspora is a term, used to describe the group of people living outside the country of origin. In modern research, Diapsora Engagement is socio, financial and cultural ties between people living outside their country and home country. Such engagement is between friends, relatives and family usually termed as informal engagement of diaspora (Merz, Chen \& Geithner, 2007). Such bonds between the people living in host and home country are considered to be an effective mean for reversing the brain. Indian IT professionals (Chacko, 2007) and Chinese return and transferring knowledge, skills and investment highlighted the importance of diaspora engagement (Zweig and Fung, 2005). Pakistan, if viably plan, can benefit from its overseas Pakistanis through actively mobilizing and engaging its diaspora. According to the United Nations Migration Report (2015), Pakistani diaspora has reached to 600,000 and became the $5^{\text {th }}$ largest diaspora of the world. If managed, mobilized and engaged properly, it can overcome the shortage of human capital. CPEC can play a vital role in this regard by attracting the highly educated, talented and qualified overseas Pakistanis. In other words the menace of brain drain can be dealt with the weapons of brain gain and brain circulation. It is worth mentioning that CPEC, although positively influence the GDP of the country, however, requires a substantial quantity of skilled and educated labor in different fields. The total 33 projects under CPEC with estimated cost of 44369.62 million dollar in energy, transport infrastructure and Gawadar project will require professional and technical skilled labor. It is in fact a challenge along with opportunity, which needs in depth planning. The immediate shortage of labor, for these projects, can be fulfilled through two ways. First to hire the existing labor in country which is although not sufficient to fulfill the supply of labor in long run due to Human Capital factor (Waheed, $11^{\text {th }}$ May 2016) and the second option which is more appealing and feasible is attracting talented people from abroad through engaging Pakistani diapsora. According to the Bureau of immigration and Overseas Employment (2015) total 59,941 engineers have emigrated from the country to 
other regions of the world. It is pertinent to mention that 7,322 engineers left the country only in 2015. Hence, these engineers, if returned, can add their share to the nation's economic development by saving billions of dollars in terms of labour costs. Besides, contributing its skill directly to the country's economic development, Pakistani diaspora can directly invest in areas created by CPEC including industrial, financial and agricultural cooperation, tourism, health care, and human resource development, etc . All the investment sites from Khunjarab to Gwadar, are identified by Borad of Investment (BOI, n.d).

\section{Diaspora Engagement Model}

Diaspora engagement helps a country of its origin in socio economic development. This engagement can be expedited through mega projects, such as CPEC. Consequently, not only the ideas, knowledge, skills and investment are directed back to the home country, but it helps in brain gain and brain circulation. Resultantly, the diaspora and the home country create a win-win situation. However, to materialize the engagement of the diaspora, the following model of Agunias \& Newland (2009), Fig.1,, should be adopted by the government of the home country.

Fig.1.

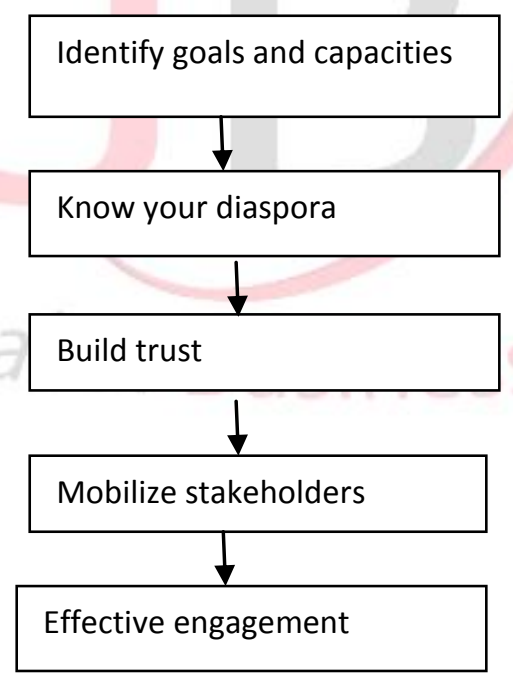

Source: Agunias and Newland (2009)

Agunias and Newland (2009) model of diaspora engagement is best suited in the socioeconomic set up of Pakistan. The model is a five-step process, which leads to effective engagement of diaspora.

\section{Step 1. Identify goals and capacities}

The first step of effective engagement is to identify the goal and capacities of diaspora. 
Why diaspora should be engaged? Either for any specific purpose like investment or fulfillment of labor requirement etc.? Such questions should be asked for effective engagement. The Ghanaian government project of MIDA Ghana Health Project is an example of it, which wanted to engage its medical doctors resided in the three European countries i.e, The Neatherlands, the United Kingdom and Germany. The engagement was to fulfill the deficiency of health practitioners and enhance the health care system of Ghana. Hence, the government launched the MIDA Ghana project (MIDA, 2010). Similarly, Chinese government called its diaspora resided in the USA and Europe in early 1990s to put their share in education, investment and research ( Zewag, 2004). The government of Pakistan should also identify its clear goals prior to engaging its diaspora. Athough, Ihsan Iqbal - the Minister for Planning, Development and Reform, has rightly explored the power of diaspora, hence giving importance in its economic reforms by propagating the motto of "I am raising Pakistan" (Ministry of Planning, Development and Reform, n.d). Describing the importance of Pakistanis' input he stated that "we must work harder, better and smarter to secure competitiveness in all fields, which is a key to sustained growth"("Ministry of Planning, Development and Reform, n.d"). The Ministry also seeks to attract the Pakistani diaspora for national development which can be cleared from the banner on its website read as "Calling top overseas PAKISTANI TALENT to contribute in the National Building" (Ministry of Planning, Development and Reform, n.d). However, how it would call its overseas Pakistanis, needs strategic planning by the government.

\section{Step 2. Know your diaspora:}

It is pertinent to mention that without knowing the diaspora, the engagement cannot be accomplished. Knowledge in terms of exact population, opinions of the members, and skill inventory of the population etc, are the factors deemed important for engagement. A comprehensive research study of the host countries and organizations where the diaspora members are working is required which should be followed by a viable strategic plan. It would help the government to know the who, where and what of the diaspora members. Although, National Talent Pool by the Presidential Program, for Care of Highly Qualified Overseas Pakistanis is a good initiative for collecting the relevant information and maintaining a database for the highly qualified expatriates ("National Talent Pool", n.d.), however, it should be more detailed and systematic in its utilization and access.

\section{Step 3. Build Trust}

More than six million Pakistanis can fulfill the requirement of labor shortage, supply of a substantial foreign direct investment and source of knowledge / skill transfer subject to the existence of "trust" created by the government. A surety by the government, accompanied by transparency provided to the overseas Pakistanis, can smoothly materialize the effective engagement of diaspora. This can be achieved through devising a multi prong strategy including revising the existing, and framing new policies such a 
dual citizenship, flexibility in project implementation, special privileges to expatriates in terms of visa etc, explanation of diapsora policy and a mechanism of feedback and above all the interventions with the governments of host countries.

\section{Step 4. Mobilize stakeholders}

It is the most significant and critical stage of the model, which should be implemented delicately. Certain measures such as high profile events, seminars, and conferences, should be arranged by the government, sponsoring the opinion members, and highly qualified expatriates. There should be a mechanism, which leads to the integration of diaspora members in the national development plan. In other words, the diaspora members should be involved in the diaspora policy by valuing their feedback. The investors should be facilitated to the maximum level by establishing "centers for guidance". It can be achieved, if government set the institutions up in federal and provincial level, which can be further extended in district level. Above all, a partner-ship scheme should be offered to the diaspora members for the effective mobilization of their investment and skills.

\section{Step 5. Effective Engagement of Diaspora}

All the above steps if implemented in a systematic manner can assure the effective engagement of Pakistani Diaspora for Socio-economic development and nation building.

\section{Recommendations}

A set of recommendations are mentioned below, which if implemented, can help achive the government's dream of sustainable socio- economic progress, however, a proper strategic plan is it's utmost requirement.

1. Government should devise "diaspora engagement policy" with the consensus of all stakeholders including media, education institutions and society and due space should be given to "the diaspora policy" while framing national economic plan. Besides, "diaspora center" or "department for diaspora affairs" should be established on federal level, which than cascaded to provincial, district and even at union council or town council level. The local governments can play a vital role in this regard, however, supported by the federal and provincial governments.

2. Procedural and policy reforms should be made in National Talent Pool. It should not be merely a database, rather a skill inventory which can be effectively utilized, if required.

3. Developmental mega project like CPEC is a source for reversing over "brain" which can ultimately lead to "brain gain" and "brain circulation". Hence, further research is required for assessing the demand of human capital utilization in CPEC. It would help the government to effectively engage the diaspora. 
4. As discussed earlier, media should play its role by highlighting the issue of brain drain and persuade the youth and talented expatriate to "return" to their motherland - in terms of knowledge, skills, ideas and investment.

5. Educational policy should be revised and aligned with the objectives of "brain gain". This can only be possible if graduate and post graduate curriculum could be designed to achieve "Academia-Industry Relationship". Although government is striving hard to complete the education policy reforms till 2017, however, it should be taken into account that the "Human Capital" factor is also considered while framing the policy.

\section{Conclusion}

The purpose of the research article is to focus on the importance of CPEC and its impact on brain drain of Pakistan. Diaspora engagement has been identified as an effective tool for reversing the brain drain of Pakistani Human Capital. CPEC would have a positive impact on the socio-economic landscape of the country; however, proper policy needs to be chalked out by the government. Diaspora engagement is specifically highlighted owing to the reason it gives a sense of ownership among the overseas Pakistanis for the accomplishment of the "multibillion game changer". The local and overseas Pakistanis should be involved in the project only through mobilization and engagement just like China (Zeiwag, 2004) and India (Chacko, 2007) did. Although, the present research article gives an insight to socio-economic impact of CPEC on Pakistan. However, further researches should be conducted, specifically, empirical investigations should be done to suggest an amicable solution of the problem.

\section{References}

ADP, 2016-17( $1^{\text {st }}$ June, 2016). Ministry of Planning, Development and Reforms retrieved from

www.pc.gov.pk/wp-content/uploads/2016/06/AnnualPlan2016-17.pdf

Afridi, F,K and Baloch, Q,B. (2015). Preventing and Reversing Pakistan's Brain Drain: An Empirical Analysis of Public Sector Universities of Khyber Pakhtunkhwa, Abasyn Journal of Social Sciences, 8(2)

Afridi, F,K. \& Urooj, Saima. (2020). A Need for Linking Universities Curriculum with China Pakistan Economic Corridor. Journal of Managerial Sciences. 14 (4), 2127

Agunias, D. R and Newland, K. (2012). Engaging the Asian Diaspora. Migration Policy Institute, retrieved from http://www.migrationpolicy.org/research/engagingasian-diaspora

Ahmad, S. A., Cho, Y. \& Faseeh, T. (2019). Pakistan@100 Human Capital, Policy Note World Bank Group, World Bank

Bureau of imigration \& overseas employment during the period. (2014). http://www.beoe.gov.pk/migrationstatistics.asp retrieved on 
Butt, N. (July 16 2016). 180 billion spent on CPEC Projects. Business Recorder. Retrived from http://www.brecorder.com/business-andeconomy/189:pakistan/65660:rs-180-billion-spent-on-cpec-projects/?date=201607-16

Chacko, E. (2007) "From brain drain to brain gain: Reverse migration to Bangalore and Hyderabad, India's globalizing high tech cities", Geo Journal, vol. 68, pp. 131140.

Diverse Investment Opportunities (n.d.) Board of Investment retrieved form http://boi.gov.pk/InfoCenter/CPEC.aspx

Dodani, S and Laporte, R,E.(2005). Brain drain from developing countries: how can brain drain be converted into wisdom gain? Journal of the Royal Society of Medicine, 98(11): 487-491

Imran, N, Azeem Z, Haider, I.I, Bhatti, M.R.( 2012) Brain Drain: A harsh reality. International migration of Pakistani medical graduates. Journal of Postgraduate Medical Institute; 26: 67-72.

International Migration Report .(2017). Retrieved from http://www.un.org/en/development/desa/population/migration/publications/migr ationreport/docs/MigrationReport2015_Highlights.pdf.

Khan, B. ( $3^{\text {rd }}$ December, 2015). Pakistan,s Economy is Turning a Corner. Retrieved from https://www.sc.com/BeyondBorders/pakistan-economy/

Merz, B, J., Chen L, C, and Geithner, P, F. (2007). "Overview: Diasporas and Development." In Diasporas and Development, edited by Barbara J. Merz, Lincoln C. Chen and Peter F. Geithner. Massachusetts: Global Equity Initiative. $1-23$

MIDA Ghana Health Project (2010). International Organization for Migration Retrieved from https://www.aspeninstitute.org/content/uploads/files/content/docs/GHD/4.\%20iv \%20Migration\%20and\%20Development $\% 20$

\%20MIDA\%20Ghana\%20Health\%20Project.pdf.

Ministry of Planning, Development and Reform. (n.d.). People must adopt I am raising Pakistan motto. Retrieved form http://www.pc.gov.pk/?p=6441

National Talent Pool.(n.d.) retrieved from http://talentpool.gov.pk/functions.html

Pakistan Engineering Council.(2014). No of registered PEC engineers, retrieved from http://www.pec.org.pk/

Personal remittances, received \% of GDP (n.d), The World Bank, retrieved from https://data.worldbank.org/indicator/BX.TRF.PWKR.DT.GD.ZS 
Rakisits,C.(2015). A Path to the Sea: China's Pakistan Plan.World Affairs retrieved from http://www.worldaffairsjournal.org/article/path-sea-china's-pakistan-plan

Sajjad, N. (2011). Causes and Solutions to Intellectual Brain Drain in Pakistan, The Dialogue, 39(6). 32-55, retrieved from http://www.qurtuba.edu.pk/thedialogue/The\%20Dialogu e/6_1/Dialogue_January_March2011_31-55.pdf

Waheed, H. (11 ${ }^{\text {th }}$ May, 2016). CPEC: a game changer or myth? Daily Times retrieved from http://dailytimes.com.pk/opinion/11-May-16/cpec-a-game-changer-or-myth

Zhen,S. (11 November, 2015). Chinese firm takes control of Gwadar Port free-trade zone in Pakistan. South China Morning Post. Retrived from http://www.scmp.com/business/companies/article/1877882/chinese-firm-takescontrol-gwadar-port-free-trade-zone-pakistan

Zweig, D. (2004).Learning to compete: China's efforts to encourage a "reverse brain drain" retrieved from http://www.google.com.pk/url?sa=t\&rct=j\&q=china\%20strategies\%20to\%20gai n\%20brain\&source $=$ web \&cd $=8$ $\&$ cad $=$ rja\&uact $=8 \&$ ved $=0$ CGMQFjAH\&url $=$ http $\% 3 \mathrm{~A} \%$ 2F\%2Fwww.cctr.ust.hk\%2Fmaterials \%2Flibrary\%2F20 050201_LearningtoCompete.pdf\&ei=wPN4U9J44ZDQ BYfpgZgI\&usg=AFQjCNFmw5siEvok1OE1hT0GS8PFnJDy7w)

Zweig, D. \& Fung. C.S. (2005). Redefining the brain drain: China's "diaspora option." Working Paper no. 1, Center on China's Transnational Relations, Hong Kong University of Science and Technology, Chinese University of Hong Kong, Hong Kong. http:// www.cctr.ust.hk/materials/working_papers/ WorkingPaper1.pdf. 